
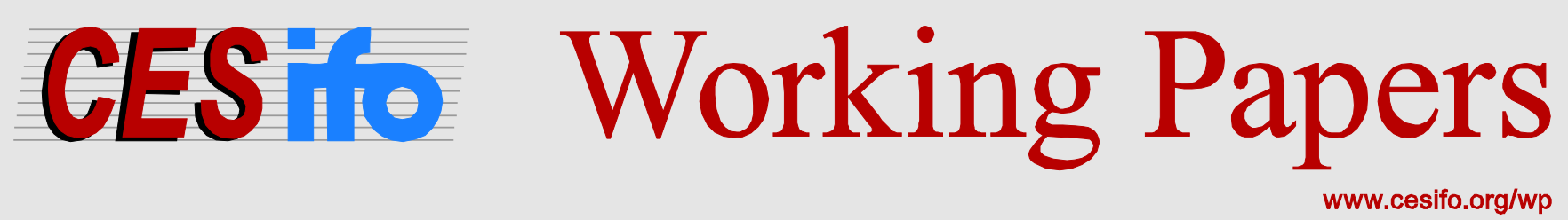

\title{
Unemployment in a Just Economy
}

\author{
John Komlos
}

CESIFO WORKING PAPER NO. 5974

CATEGORY 4: LABOUR MARKETS

JUNE 2016
An electronic version of the paper may be downloaded
- from the SSRN website:
- from the RePEc website:
- from the CESifo website:
www.SSRN.com
www.RePEc.org
www.CESifo-group.org/wp




\title{
Unemployment in a Just Economy
}

\begin{abstract}
This paper is based on the ideas of political philosopher John Rawls who suggested that a just society is one which would be created behind a "veil of ignorance", that is to say, without knowing where one would end up in the society's distribution of talent and other attributes valued in the labor market. Today's labor market does not meet this criterion inasmuch as risk averse people would not be willing to enter it at random, being too concerned about ending up among the excluded, i.e., those without full time jobs which today in the U.S. is still $10 \%$ of the labor force or some 15 million people (Bureau of Labor Statistics, 2014). This is substantial but it does not even include about 5 million additional people who have dropped out of the labor force altogether or the 2.3 million convicts in jail.

Thus, a just labor market would strive for full employment beyond the implications of NAIRU. The latter concept is actually misleading, because most economists and commentators in the media equate it with "full employment". As a consequence, endemic and large scale un- and underemployment is accepted as an inevitable attribute of the labor market. This is insidious inasmuch as the concept assumes that the institutional structure of the labor market is held constant. According to Rawlsian principles the aim should be to bring unemployment down to the minimum feasible rate which in the U.S. is most likely around $1.2 \%$,--the rate which prevailed in 1944 and which probably represents an attainable lower bound. Instead of the prevailing system, the right to work needs to be recognized as a natural right, because the right to life depends upon it. Several ways are proposed to create an inclusive labor market that distributes the available work in a more equitable fashion than the current system and envisions a just economy on Rawlsian principles that risk-averse people would be willing to enter at random.
\end{abstract}

JEL-Codes: B000.

Keywords: labor market, justice, full employment, natural rate of unemployment, NAIRU, John Rawls.

John Komlos

Professor Emeritus

University of Munich / Germany

john.komlos@gmx.de 


\section{Introduction}

To human beings fairness is an essential aspect of life. So is justice. In fact, they are so important that people are willing to sacrifice a lot to fight for it, not infrequently even their lives. "Universal values of fairness" was a main motivation of recent demonstrations as far removed from one another as Tahrir Square and Zuccotti Park, many of which toppled governments (Stiglitz, 2013, p. xxxviii). "Justice is a human virtue" (Schmoller et al, 1894, p. 4). Indeed, fairness is so central to humans - and not only to humans, as other primates are similarly inclined - that one can infer that it has evolutionary roots (Brosnan and de Waal, 2003; Heinrich, 2000). The probable reason is that cooperation was crucial for the survival of the tribe; violating the rules and expectations of the norms would have been considered unfair and those who did so no doubt would have been ostracized lowering their probability of reproducing their characteristics. Thus, evolution favored the propagation of those traits that predisposed us to value fairness. We really cannot help it. It is an integral part of human nature.

In spite of the widespread prevalence of this disposition, the concept is not firmly integrated into economics, even if the founder of the discipline, Adam Smith, forcefully stressed its relevance in The Theory of Moral Sentiments of 1759, and it is alluded to occasionally, for instance, in the context of reciprocity in which workers may reduce their productivity in response to unfair treatment by their employers (Akerlof and Yellen, 1990; Bewley, 1998; Fehr, and Gächter, 2000; Skott, 2005). Nonetheless, in the main, it remains outside of the mainstream's purview, well behind such concepts as efficiency even though there is no evidence that the latter is more important to us than the former. Moreover, the concept of justice has not been applied to the labor market as a whole, although the idea of a fair wage does enter into models of wage determination (Blinder and Choi, 1990). ${ }^{1}$

This modest essay begins to fill this lacuna by using the political philosopher John Rawls' (1971) influential concept of a just society to labor markets in general and argues that their current organization does not meet the Rawlsian criterion of justice. A Rawlsian labor market conflicts with current views of full employment based on theories associated with NAIRU. ${ }^{2}$ We also discuss some institutions that would bring us closer to a just labor market in the spirit of Amartya Sen (2009) who emphasized the notion that it is important to focus on becoming a juster society or a more equal society (Atkinson, 2015, p. 301). These ideas dovetail well with the discussion concerning the problem of rampant inequality insofar as a more equal distribution of work would inevitably lead to a more equal distribution of income. 


\section{Just Labor Market}

Rawls asserts that a just society should be our ultimate goal: "Justice is the first virtue of social institutions, as truth is of systems of thought.... Laws and institutions no matter how efficient and well-arranged must be reformed or abolished if they are unjust. (1971, p. 3)." His litmus test of a just society is whether one would be willing to enter it at random without knowing anything either about ones own characteristics or where one would end up in the society's social order. After all, if one is unwilling to take the chance of entering the society at random, it would not be moral to wish it on others, as the Kantian (1785) principle of universal imperative also implies. In fact, most risk averse people would be unwilling to enter most labor markets today if they did not know their gender, race or where they will end up in the society's distribution of talents, skills, inherited wealth, IQ, looks, and other attributes valued in the market. In other words, if they had no information on their endowments and original position it would be too risky to enter it.

Thus, today's labor markets are not just according to Rawlsian principles as people would not be willing to enter it at random. People would be too apprehensive about ending up among the excluded, i.e., those without full time jobs, which in the U.S. in the Spring of 2016 is still $9.8 \%$ of the labor force or some 15 million adults. ${ }^{3}$ This is substantial but it does not even include an additional—roughly 5 million—prime-age adults who dropped out of the labor force presumably mostly on account of being frustrated with their chances of succeeding in finding employment. ${ }^{4}$ And the burden of underemployment is much greater among minorities. Among African-Americans it is $16.8 \% .^{5}$

What would a just labor market look like? Rawls argues that one would have to design it behind a "veil of ignorance", i.e., without knowing anything about one's endowments or initial position. ${ }^{6}$ Otherwise our current standing in the society is likely to sway our judgment. If one would be willing to enter it at random then it is moral to make its rules universally binding on others as well.

\section{Full employment}

If people could construct a labor market from scratch under the above specified conditions it would be such that full employment would be attained. The reason is that exante (in the original position) only through employment can one be sure to be able to sustain life. The selfish survival instinct behind the veil of ignorance then leads logically to an organization of a labor market in which there is a constitutional right to employment for then even the unlucky would be ensured to be able to satisfy at least their basic needs. 
Instead of accepting a certain amount of underemployment as natural, a Rawlsian would acknowledge that there is a natural right to life. ${ }^{7}$ Insofar as exclusion from work threatens one's very existence inasmuch as work is necessary for survival, the right to life practically implies that we need to be guaranteed the right to work. Pope Leo XIII argued similarly in his famous encyclical, Rerum Novarum. ${ }^{8}$ Moreover, the United Nation's Universal Declaration of Human Rights states that, "Everyone has the right to work ... and to protection against unemployment (United Nations, 1948)." The spirit of this pronouncement appears in many other international documents including in the French constitution: "Each person has the duty to work and the right to employment."9

However, a Rawlsian full employment would differ from today's common usage of the term insofar as full employment nowadays is commonly equated with the natural rate of unemployment (Friedman, 1968, p. 8; 1977, p. 458) or more recently with the NAIRU (the non-accelerating inflation rate of unemployment) (Phelps, 1968, 1969; Stiglitz 1997). For instance, at the January, 2016 meeting of the American Economic Association in San Francisco, Martin Feldstein declared that "We are essentially at full employment with the overall unemployment rate at five percent" (Feldstein 2016a). ${ }^{10}$ His pronouncement is not unusual at all, rather it is standard practice: Ben Bernanke made similar statements prior to the financial crisis. ${ }^{11}$ The misleading nature of the concept is magnified through the media which absorbs economists' usage and misinforms the public by insisting that $5 \%$ unemployment is "traditional full employment" (Washington Post 2014). ${ }^{12}$ As a consequence, endemic un- and underemployment, which in the U.S. amounts to some 20 million people becomes widely accepted as an inevitable characteristic of the labor market and are defined away. This is insidious inasmuch as the practice encourages policy makers to be complacent about the plight of a substantial segment of the population. That is precisely why Noble laureate William Vickrey referred to the natural rate of unemployment as "one of the most vicious euphemisms ever coined" (1992, p. 341).

What is meant, of course, is that using conventional monetary and fiscal policy we are not likely to be able to attain a level of unemployment below NAIRU which according to the Federal Reserve is in the range of 5.0\% $-6.3 \%{ }^{13}$ (Federal Reserve Bank of St. Louis, 2014; Gordon, 1997). However, these estimates are not very accurate. ${ }^{14}$ Thus, the tacit assumption of the NAIRU conceptual apparatus is that the institutional structure of the labor market is held constant (Colander, 1998; Naude' and Nagler 2015). But Rawls would suggest that this need not be the case and we should use other means to move toward a just labor market. 
One way to proceed is to consider full employment as the lowest level of unemployment physically attainable. In the U.S. that was $1.2 \%$ recorded in 1944 (even though the labor force expanded by $10 \%$ during the war) ${ }^{15}$ (Carter et al. 2006). Presumably, that level of unemployment was not related to insufficient demand for labor but must have depended on the physical or mental health of those few remaining unemployed. Of course, that was a time of war but the experience does demonstrate clearly the capacity of the economy to create job opportunities and bring unemployment down to negligible levels given the right set of circumstances.

\section{A Rawlsian labor market}

From a Rawlsian perspective the current organization of the labor market cannot be considered just because the opportunity to work - like wealth and income - is unevenly distributed across the labor force. In the U.S. about $82 \%$ of the labor force works full time, $14 \%$ works part time, $5 \%$ are unemployed, and an additional $9 \%$ are underemployed. ${ }^{16}$ Part of the problem lies in the organization of the labor market: the custom is that adjustments in the fluctuations in demand for labor generally occur mostly by reducing the number employed so that their labor time falls abruptly from 40 hours to 20 or zero. Hence, one is either given the opportunity to work roughly 40 hours or one is not allowed to work at all even though part-time work is also a possibility. Would anyone "behind a veil of ignorance" design such a rigid system from scratch, a system with so much uncertainty and instabilitywith working times ranging from 0 to 70 hours per week even in normal times. It would be more reasonable to have the adjustment occur in the number of hours worked so that instead of dismissing workers, the available work would be divided more evenly among those wanting to work. Hence, an institutional framework that would enable work to be distributed more evenly would be a reasonable solution to this quandary. ${ }^{17}$

Thus, in a Rawlsian framework one would not be satisfied with achieving a level of unemployment consistent with NAIRU. Instead, the Rawlsian aim would be to restructure the labor market in such a way that it would generate enough jobs to reduce unemployment to $1.2 \%$. One way would be to reduce the number of hours worked in a standard working day by roughly $10 \%$, the underemployment rate. This would mean a reduction of roughly an hour a day from 8 to 7 hours similarly to what happened when the 10 hour day was reduced to 8 hours. Such a work-sharing system would be a more equitable shock absorber of a decline in the demand for labor than the current system (Baker 2011).

Other arrangements that would have similar effects include profit sharing wages in which case wages would increase in good times and decrease in recessions so that workers 
would not have to be fired, keeping the share of total wages in revenue unchanged (Weitzman, 1984). Encouraging cooperatives would also be useful inasmuch as such firms are more likely to adjust pay to fluctuations in demand rather than the number employed (Craig and Pencavel 1992; Pencavel 2002, Rosen et al., 1986). One could also mandate that the government become the employer of last resort (Colander 1981) in a similar manner to the government's role as lender of last resort as provider of a backstop to the financial system $^{18}$ (Wray 1997, Colander 2009, p. 747ff). A new institution--comparable to the Federal Reserve's role in finance--could provide similar stability to the labor market ${ }^{19}$ (Atkinson 2008). It would contribute to an inclusive economy in which no one is deprived of the opportunity to work ${ }^{20}$ (Stiglitz et al, 2015; Junankar, 2011). As Stiglitz put it: "The rules can and should be rewritten, in ways that promote... employment and reduce exclusion (2016)." After all, during the New Deal the Work Progress Administration hired as many as $7 \%$ of the labor force, which in today's terms would amount to some 10 million people (Margo, 1993, p. 43). That alone would cut underemployment rate in half.

Such a system would increase the quality of life, because it would reduce the psychological burden of unemployment, increase leisure time, and reduce envy by reducing conspicuous consumption. In addition, it would be a much fairer method of distributing the pain associated with a diminution in the demand for labor than the prevailing rigid system.

\section{Rawlsian wages}

Equating wage to marginal product does not meet Rawls' criteria of justice insofar as much of it is a rent, i.e., return to attributes of the employee that are part of a random allocation. The employee did not do anything for his/her genetic endowment so that any return to characteristics that are in perfectly inelastic supply such as looks, talent, physical size, IQ ought not accrue to the employee and should be taxed at a rate of $100 \%$. Rawlsian disposable income should be entirely a function of effort that includes schooling and other investments in human capital. After all, just rewards ought not be based on the luck of a random initial allocation.

\section{Conclusion}

As the Nobel Prize winning economist Paul Krugman recently put it, "I am, and I think lots of us, are to some degree Rawlsians; that is, we think that at some level you ought to think about society in terms of what would you want if you didn't know who you would be behind a veil of ignorance. And you do not have to be a rigorous Rawlsian to feel that it is right, it's appropriate, to care more about diminishing misery at the bottom than increasing 
comfort at the top... that is a good thing from the point of view of so me notion of justice (Graduate Center, 2015, @4:00).

As currently constituted, the labor market is not just according to Rawlsian principles. His litmus test of a just society is whether we would create it behind a vail of ignorance, i.e., prior to knowing our personal characteristics and how the market will value them. Insofar as goodly share of the rewards to labor today depend fundamentally on the luck of birth such as the genetic lottery or the family of birth, Rawls asserts that risk averse people as we are, would not dare to enter today's labor market at random. Hence, it is not a just institution. We ought not to wish on others that which we would not dare to do ourselves.

Hence, Rawls would consider a just labor market one that it is at full-employment and not the one in widespread usage today based on theories associated with NAIRU and the natural rate of unemployment. As Stiglitz suggests these concepts merely provide policymakers "reasons not to attempt to address unemployment.... These ideas provided intellectual comfort to central bankers who didn't want to do anything about unemployment. But there were strong grounds for skepticism about these ideas... The underlying hypothesis that there is a stable relationship between the unemployment level and the rate of acceleration of inflation has not withstood the test of time,... The use of the term "natural unemployment rate suggests that it is 'natural' and natural things are good, or at least unavoidable. Yet there is nothing natural about the high level of unemployment we see today. And these ideas are being used by those that don't want government to take steps to do anything about it. (2013, pp. 328-329)."

In addition, Rawlsians would introduce different shock absorbers into the labor market instead of the rigid system of today. It would be much more reasonable to distribute the burden of shortfall of available work more equitably than concentrating it among some 20 million people in the U.S. $-14 \%$ of the adult population —as the labor market functions today. If one were designing a labor market from scratch, one would surely construct one that lowered the uncertainty associated with being underemployed. Working less would also increase leisure time available to improve the quality of life for the employed population.

Similar to the wartime experience, effective demand could to be increased perhaps not as Paul Krugman suggested — tongue in cheek-by declaring an impending alien invasion (Krugman, 2011), but by improving education, eradicating slums, repairing decaying infrastructure and investing in new ones, reducing pollution, and investing in renewable energy. There is no shortage of productive investments. These projects could create enough 
jobs to achieve full employment for many years to come (Brenner and Brenner-Golomb 2000, Vickrey 1992, Warner, et al., 2000).

"Work is a necessity, part of the meaning of life on this earth, a path to growth, human development and personal fulfilment" (Francis, 2015, paragraph 128). A fairer distribution of work would be important not only to provide the means to making a living but also because underemployment has destabilizing social and political effects ${ }^{21}$ (ILO, 2008; Pius XI, 1931). Underemployment generates negative externalities such as an increase in criminality and an increase in stress and anxiety about losing one's job. Work is important also from a psychological perspective: underemployment is degrading and makes one feel unwanted (Muqtada, 2010; Junankar, 2011; UNDP, 2014). The underemployed do not consider themselves useful members of the society and suffer from diminished self-esteem. Their skill depreciates during extended spells of unemployment so that it becomes more difficult for them to find a job. In other words, underemployment increases social misery. For instance, the underemployed are twice as likely to be sad or depressed than the employed and 50\% more likely to be angry (Marlar 2010). They are also more likely to be struggling financially (54\%) in contrast to $38 \%$ of the employed (Manchin 2012). This is hardly a negligible matter, especially since endemic underemployment is likely to be with us for the foreseeable future (Summers 2014a, 2014b; Brynjolfsson and McAfee, 2012) unless we begin to think creatively about Rawlsian approaches to full employment. Thus, the concept of the natural rate of unemployment "is an idea that is past its sell-by-date" (Farmer, 2013; Galbraith, 1997). "It is essential that "we continue to prioritize the goal of access to steady employment for everyone" (Francis, 2015, paragraph 127). This is particularly important at the current level of inequality as Atkinson asserts: "the present levels of economic inequality are intrinsically inconsistent with the conception of a good society." A good society or a just society? Either way, it should be clear that we have a long road ahead of us.

\section{References}

Akerlof, George, A. and Yellen, Janet L. 1990. "The fair wage-effort hypothesis and unemployment," Quarterly Journal of Economics 105: 254-283,

“Alan Greenspan on Income Inequality," YouTube video, posted by johnklin, September 28, 2007, accessed May 29, 2016.

Atkinson, Anthony, 2008. "Unequal growth, unequal recession?" OECD Observer, http://www.oecdobserver.org/news/archivestory.php/aid/2751/Unequal_growth,_unequal_rec ession .html accessed May 21, 2016. 
Atkinson, Anthony, 2015. Inequality. What can be done? Harvard University Press.

Baker, Dean. 2011. Work Sharing: The Quick Route Back to Full Employment

(Washington, D.C.: Center for Economic and Policy Research),

http://www.cepr.net/documents/publications/work-sharing-2011-06.pdf (accessed May 21, 2012).

Bewley, Truman F. 1998 "Why not cut pay?," European Economic Review 42: 459490.

Blinder, Alan S. and Choi, Don H. 1990. "A Shred of Evidence on Theories of Wage Stickiness," Quarterly Journal of Economics, 105: 1003-1016.

Brenner, Yehojachin Simon and Brenner-Golomb, Nancy. 2000. A Theory of Full Employment, $2^{\text {nd }}$ ed (New Brunswick, NJ: Transaction Publishers).

Brosnan, Sarah F. and de Waal, Frans, B.M. 2003, "Monkeys reject unequal pay," Nature 425: 297-299.

Brynjolfsson, Erik and McAfee, Andrew. 2012. Race Against the Machine: How the Digital Revolution is Accelerating Innovation, Driving Productivity, and Irreversibly Transforming Employment and the Economy, Digital Frontier Press.

Bureau of Labor Statistics, Table A-15. Alternative measures of labor underutilization. http://www.bls.gov/news.release/empsit.t15.htm accessed June 16, 2014.

Carter, Susan B., Gartner, Scott Sigmund, Haines, Michael, R. Olmstead, Alan L. Sutch, Richard and Gavin Wright, 2006. Historical Statistics of the United States. Millennial Edition online. Cambridge: Cambridge University Press, Table Ba470-477 - Labor force, employment, and unemployment: 1890-1990.

Colander, David. 1981. "A Guaranteed Jobs Proposal,” in David Colander (ed.), Solutions to Unemployment (New York: Harcourt Brace Jovanovich, Inc.), pp. 204-208.

Colander, David, 1998. "Macroeconomics: Was Vickrey Ten Years Ahead?" Challenge, 41, 5: 72-86.

Colander, David, 2009. Economics. New York: McGraw-Hill.

Craig, Ben and Pencavel, John. 1992. "The Behavior of Worker Cooperatives: The Plywood Companies of the Pacific Northwest," American Economic Review 82, 5: 10831105.

Du, Zaichao, Yin, Hua, and Zhang, Lin. 2013. "The macroeconomic effects of the 35 h workweek regulation in France," B.E. Journal of Macroeconomics 13(1): 881-901.

Farmer, Roger E.A. 2013. "The Natural Rate Hypothesis: an idea past its sell-bydate," Bank of England Quarterly Bulletin Q3: 244-256. 
Federal Reserve Bank of St. Louis. Economic Research. http://research.stlouisfed.org/fred2/series/NROU accessed June 16, 2014.

Fehr, Ernst and Gächter, Simon, 2000. „Fairness and retaliation: the economics of reciprocity," Journal of Economic Perspectives, 14, 159-181.

Feldstein, Martin, 2015. “What is Full Employment?," Project Syndicate June 29, https://www.project-syndicate.org/commentary/what-is-full-employment-by-martin-feldstein2015-06?barrier=true accessed May 7, 2016.

Feldstein, Martin, 2016a. "Dealing with Long-Term Deficits,“ American Economic Review: Papers \& Proceedings, 106, 5: 35-38.

Feldstein, Martin, 2016b. “The U.S. Economy Is in Good Shape,” The Wall Street Journal, February 21, http://www.wsj.com/articles/the-u-s-economy-is-in-good-shape1456097121 accessed May 7, 2016.

Francis, 2015. "Laudato Si," Encyclical letter on Care for our Common Home, http://w2.vatican.va/content/francesco/en/encyclicals/documents/papafrancesco_20150524_enciclica-laudato-si.html\#_ftnref103 accessed May 23, 2016.

Friedman, Milton, 1968. "The role of monetary policy," American Economic Review $58,1-17$.

Friedman, Milton, 1977. "Nobel Lecture: Inflation and Unemployment," Journal of Political Economy 85, 3, 451-472.

Galbraith, James, K. 1997. "Time to Ditch the Nairu," The Journal of Economic Perspectives 11, 1: 93-108.

Gordon, Robert, J. 1997. “The Time-Varying NAIRU and its Implications for Economic Policy," The Journal of Economic Perspectives 11, 1: 11-32.

Graduate Center, CUNY, 2015. "Robert Solow in Conversation with Paul Krugman: “Inequality: What Can Be Done?," YouTube video, posted May 22, 2015, accessed May 29, 2016.

Heinrich, Joaeph, 2000. "Does culture matter in economic behavior? Ultimatum game bargaining among the Machiguenga of the Peruvian amazon," American Economic Review 90: 973-979.

Internation Labour Organization, 2008. "ILO Declaration on Social Justice for a Fair Globalization," http://www.ilo.org/wcmsp5/groups/public/---dgreports/--cabinet/documents/genericdocument/wcms_371208.pdf accessed May 21, 2016. 
Jackson, Lucas, 2016. "Fed's Bullard says global headwinds appear to have waned, Brexit no risk," Reuters, May 5, http://www.reuters.com/article/us-usa-fed-bullardidUSKCNOXW1OL accessed May 7, 2016.

Junankar, P.N. Raja, 2011. "The Mirage of Full Employment,” Working paper, University of New South Wales.

Kant, Immanuel, 1785. Grundlegung zur Metaphysik der Sitten.

Krugman, Paul. 2010. "Kurzarbeit," The New York Times, September 2, 2010, http://krugman.blogs.nytimes.com/2010/09/02/kurzarbeit/ accessed May 20, 2014.

Krugman, Paul, 2011. "Coalmines and Aliens," The New York Times, August 24, 2011. http://krugman.blogs.nytimes.com/2011/08/24/coalmines-and-aliens/ accessed June 16, 2014.

Leo XIII, 1891. "Rerum Novarum,” Encyclical letter on Capital and Labor; http://w2.vatican.va/content/leo-xiii/en/encyclicals/documents/hf_lxiii enc 15051891 rerum-novarum.html accessed May 23, 2016.

Manchin, Anna. 2012. "Depression Hits Jobless in UK, U.S. More than in Germany," Gallup, November 21, http://www.gallup.com/poll/158879/depression-hits-joblessgermany.aspx (accessed July 21, 2014).

Margo, Robert A. 1993. "Employment and Unemployment in the 1930s," Journal of Economic Perspectives 7, 2: 41-59.

Marlar, Jenny. 2010. "The Emotional Cost of Underemployment," Gallup, March 9, http://www.gallup.com/poll/126518/Emotional-Cost-Underemployment.aspx accessed May 6, 2014.

Muqtada, Muhammed, 2010. "The crisis of orthodox macroeconomic policy : the case for a renewed commitment to full employment," International Labour Office, Employment Sector working paper. - Geneva: ILO; http://www.ilo.org/wcmsp5/groups/public/@ed_emp/documents/publication/wcms_127678.p df accessed May 21, 2016.

Naude', Wim and Nagler, Paula, 2015. "Industrialisation, Innovation, Inclusion," United Nations University, Working Paper Series, no. 2015-043.

Olivetti, Claudia, M. Daniele Paserman, Laura Salisbury, "Three-generation Mobility in the United States, 1850-1940: The Role of Maternal and Paternal Grandparents," NBER Working Paper No. 22094.

Pencavel, John. 2002. Worker Participation. Lessons from the Worker Co-ops of the Pacific Northwest ( New York: Russell Sage Foundation). 
Phelps, Edmund, S. 1968. "Money-Wage Dynamics and Labor-Market Equilibrium," Journal of Political Economy, 76: 678-711.

Phelps, Edmund, S. 1969. "The New Microeconomics in Inflation and Employment Theory," American Economic Review: Papers and Proceedings, 59: 147-160.

Pius XI, 1931. “Quadragesimo Anno," Encyclical letter on Reconstruction of the Social Order, http://w2.vatican.va/content/pius-xi/en/encyclicals/documents/hf_pxi_enc_19310515_quadragesimo-anno.html accessed May, 23, 2016.

Rawls, John. 1971. A Theory of Justice (Cambridge, MA: Harvard University Press).

Rosen, Corey, M., Klein, Katherine J. and Young, Karen M. 1986. Employee Ownership in America. The Equity Solution. Lexington, MA: Lexington Books.

Schmoller, Gustav, Ernst L. von Halle, and Carl L. Schutz, 1894. „The Idea of Justice in Political Economy, “The Annals of the American Academy of Political and Social Science, 4: 1-41,

Skott, Peter. 2005. „Fairness as a source of hysteresis in employment and relative wages, “ Journal of Economic Behavior \& Organization 57, 3: 305-331.

Staiger, Douglas, Stock, James H. and Watson, Mark, W. 1997. "The NAIRU, Unemployment and Monetary Policy," The Journal of Economic Perspectives, 11, 1: 33-49.

Stiglitz, Joseph. 1998. „Reflections on the Natural Rate Hypothesis,” The Journal of Economic Perspectives 11, 1: 3-10.

Stiglitz, Joseph, 2013. The Price of Inequality. How Today's Divided Society Endangers our Future, W.W. Norton \& Co paperback.

Stiglitz, Joseph, 2016. "Restoring Equitable and Sustainable Economic Growth in the United States," American Economic Review: Papers \& Proceedings, 106, 5: 43-47.

Stiglitz, Joseph, Nell Abernathy, Adam Hersh, Susan Holmberg and Mike Konczal, 2015. Rewriting the Rules of the American Economy, W.W. Norton.

Summers, Lawrence, 2014a. "U.S. Economic Prospects: Secular Stagnation, Hysteresis, and the Zero Lower Bound," Business Economics, 49, 2: 65-73.

Summers, Lawrence, 2014b. "Low Equilibrium Real Rates, Financial Crisis, and Secular Stagnation," In Martin Neil Baily \& John B. Taylor (ed.). Across the Great Divide: New Perspectives on the Financial Crisis, " Hoover Institution, Stanford University, number 8, pp. 37-50.

United Nations, 1948. "The Universal Declaration of Human Rights," http://www.un.org/en/documents/udhr/index.shtml (accessed June 13, 2014). 
UNDP, 2014. Human Development Report 2014. Sustaining Human Progress:

Reducing Vulnerabilities and Building Resilience, United Nations Development Programme, http://hdr.undp.org/en/content/human-development-report-2014 accessed May 21, 2016.

Van der Veen, Robert J. 1998. "Real Freedom versus Reciprocity: Competing Views on the Justice of Unconditional Basic Income,” Political Studies 46, 1: 140-63.

Van der Veen, Robert and Groot, Loek (eds.), 2000. Basic Income on the Agenda: Policy Objectives and Political Chances, Amsterdam University Press.

Van Parijs, Philippe, 1991. "Why Surfers Should be Fed. The Liberal Case for an Unconditional Basic Inomce,” Philosophy \& Public Affairs 20: 101-131.

Vickrey, William. 1992. "Chock-Full Employment without Increased Inflation," American Economic Review, 82, 2: 341-45.

Warner, Aaron, W., Forstater, Mathew, W., and Rosen, Sumner M. 2000.

Commitment to Full Employment. The Economics and Social Policy of William S. Vickrey (New York: M.E. Sharpe).

Washington Post, "A brief history of U.S. unemployment. http://www.washingtonpost.com/wp-srv/special/business/us-unemployment-rate-history/ Accessed June 13, 2014.

Weitzman, Martin. 1984. The Share Economy Cambridge: Harvard University Press.

Wray, L. Randall. 1997. “Government as Employer of Last Resort: Full Employment Without Inflation,” Levy Economics Institute Working Paper No. 213.

Zumbrun, Josh, 2015. 'Economists See U.S. on Cusp of 'Full' Employment, WSJ Survey Says," The Wall Street Journal, October 8, http://www.wsj.com/articles/economists-

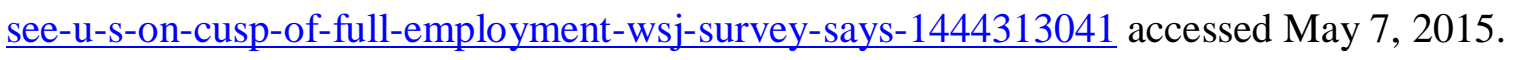

\section{Endnotes}

1 The Rawlsian conception of justice has surfaced in the discussion of basic income. (Van der Veen, 1998; Van Parijs, 1991; Van der Veen and Groot, 2000).

2 "In an important sense, the US economy is now at full employment" (Feldstein, 2015).

${ }^{3}$ Federal Reserve Bank of St. Louis, Economic Research, https://research.stlouisfed.org/fred2/series/U6RATE accessed April 29, 2016.

${ }^{4}$ Calculated as $3 \%$ of adults. The number of adults not of retirement age is around 200 million. U.S. Census, “Age and Sex Composition: 2010,” Census Briefs May, 2011, https://www.census.gov/prod/cen2010/briefs/c2010br-03.pdf accessed April 20, 2016; 
Federal Reserve Bank of St. Louis, Economic Research, https://research.stlouisfed.org/fred2/series/LNS11300060 accessed April 29, 2016.

${ }^{5}$ The State of Working America, http://stateofworkingamerica.org/charts/underemploymentby-race-and-ethnicity/ accessed May 12, 2016.

${ }^{6}$ This concept bears some similarity to Adam Smith's use of an omniscient ideal being in The Theory of Moral Sentiments of an "impartial spectator" (1759) and in general to the philosophical concept of an "ideal observer".

${ }^{7}$ The Declaration of Independence also asserts the unalienable Right to "Life"; http://www.archives.gov/exhibits/charters/declaration_transcript.html accessed May 13, 2016.

8 "The preservation of life is the bound duty of one and all, and to be wanting therein is a crime. It necessarily follows that each one has a natural right to procure what is required in order to live, and the poor can procure that in no other way than by what they can earn through their work." (Leo XIII, 1891, Paragraph 44).

${ }^{9}$ From the Preamble to the French Constitution of 1946 which is still valid today. http://www.conseil-constitutionnel.fr/conseil-constitutionnel/root/bank_mm/anglais/cst3.pdf accessed May 13, 2016. See also the work of the Internationl Labour Organization whose stated goal is "to achieve full and productive employment and decent work for all..." (Muqtada 2010, p. iii). These values were already annunciated in the ILO's Constitution including the Declaration of Philadelphia of 1944 (ILO, 2008). A recent UNDP report asserts that "Universalism... also applies to labour markets - ensuring that everyone has access to decent opportunities for paid employment" (2014, p. 92).

${ }^{10}$ https://www.aeaweb.org/webcasts/2016/Economy.php accessed April 19, 2016. Repeated in the media (Feldstein 2016b)

${ }^{11}$ He said in 2005 that "House price will slow, maybe stabilize, might slow consumption spending a bit; I don't think it's going to drive the economy too far from its full employment path though." At a time when he spoke of full employment there were 7.6 million people officially unemployed, 5 million wanted a job but were discouraged to search and 4 million were working part time although they wanted full time work. "Ben Bernanke Was Wrong," YouTube video, posted by "Marcus C. Macellus," July 22, 2009. https://www.youtube.com/watch?v=9QpD64GUoXw accessed August 30, 2014. 12 According to The Wall Street Journal, "The U.S. economy is at last on the cusp of full employment... The U.S. will be in a state of full employment within the first half of 2016 
according to $56 \%$ of the economists surveyed" (Zumbrun, 2015). Note, however, that the term "full employment" is usually qualified in mysterious ways either by putting it into quotation marks or by referring to it as "traditional full employment" or "essentially in full employment". The implications of these qualifiers must elude the average reader. Here is another formulation citing St. Louis Federal Reserve President James Bullard: "the labor market is "at or possibly well beyond reasonable conceptions of full employment"' (Jackson, 2016).

${ }^{13}$ It is not a constant. The Federal Reserve raises it slightly when unemployment is high and decreases it when unemployment is low.

${ }^{14}$ The $95 \%$ confidence interval was estimated on the late- $20^{\text {th }}$-century data to have a width of 3 percentage points (Staiger et al., 1997, p. 34).

${ }^{15}$ Unemployment was also as low in 1918.

${ }^{16}$ This includes those part-time workers who would like to work full time and about 5 million people who are not officially in the labor force but would like to work if the opportunity arose.

${ }^{17}$ Some tentative steps in this direction were taken in the 2012 "Job Creation Act." Such a program works in Germany where total employment has not decreased at all during the Meltdown (Krugman, 2010). The reduction of the workweek in France from 39 to $35 \mathrm{hrs}$ in large firms in the year 2000 is estimated to have reduced unemployment rate by $1.6 \%$ by 2002 (Du, Yin, and Zhang 2013).

${ }^{18}$ Atkinson calls for "The government... to offer guaranteed public employment at the minimum wage to those who seek it $(2015$, p. 303)."

19 "If governments can take on the role of lender of last resort, then we should be willing to see government as the employer of last resort" (Atkinson, 2008).

${ }^{20}$ Moreover, in the age of the information technology (IT) revolution it ought to be possible to match vacancies to willing workers instantaneously, thereby eliminating frictional unemployment completely.

${ }^{21}$ As the Nobel Prize winning economist Robert Solow put it: "Extreme Inequality is bad for the democratic political process” (Graduate Center, 2015, @3:06 minutes). He also calls it "repulsive" and "immoral." Even conservative ex-Federal Reserve Chairmen Alan Greenspan expressed the opinion that "if you have an increasing sense that the rewards of capitalism are being distributed unjustly, the system will not stand"(Alan Greenspan 2007,@2:36). 